To cite: FM Ndahinda 'Peoples' rights, indigenous rights and interpretative ambiguities in decisions of the African Commission on Human and Peoples' Rights' (2016) 16 African Human Rights Law Journal 29-57

http://dx.doi.org/10.17159/1996-2096/2016/v16n1a2

\title{
Peoples' rights, indigenous rights and interpretative ambiguities in decisions of the African Commission on Human and Peoples' Rights
}

\author{
Felix M Ndahinda* \\ Assistant Professor, Tilburg Law School, The Netherlands; Senior Lecturer, \\ University of Rwanda
}

\begin{abstract}
Summary
The evolving jurisprudence of the African Commission on Human and Peoples' Rights displays ambiguities in interpretations of the peoples' rights provisions of the African Charter on Human and Peoples' Rights. The article comparatively examines the Endorois and Southern Cameroon decisions adopted in 2009 in an effort to uncover the challenges faced by the African Commission in contextually applying peoples' rights provisions of the African Charter to particular collectives. In the Endorois case, the Commission made a positive finding on violations of applicants' claims of violations of their collective rights as an indigenous people. Conversely, in the Southern Cameroon case, the Commission made a negative finding on the applicants' arguments for remedial secession, using more or less the same collective rights provisions of the African Charter. The article contextualises the two cases in critically examining the African Commission's legal reasoning in both decisions.
\end{abstract}

Key words: indigenous; peoples; African Commission; jurisprudence; ambiguities

* LLM (Lund, Sweden) PhD (Tilburg, The Netherlands); ndamuk@gmail.com 


\section{Introduction}

More than three decades since the adoption of the African Charter on Human and Peoples' Rights (African Charter), ${ }^{1}$ uncertainty persists over the boundaries of applicability of "peoples" rights provisions codified in the instrument. In 2009, the African Commission on Human and Peoples' Rights (African Commission) concluded its deliberations in two important communications that extensively invoked the peoples' rights provisions of the African Charter. In Gunme \& Others $v$ Cameroon, ${ }^{2}$ the African Commission found numerous violations of applicants' rights by the respondent, but made a negative finding about their central claims for self-determination in the form of secession. In the second case, presented in the name of members of the Endorois community against Kenya (Endorois case), ${ }^{3}$ the African Commission found violations of numerous collective rights. The Commission further made an unambiguous pronouncement regarding the identity of the Endorois as constitutive of an indigenous people. The Endorois decision has been celebrated widely as a landmark achievement in vindicating indigenous rights on the African continent. ${ }^{4}$ However, in these two and prior cases, the African Commission's interpretation of peoples' rights in the African Charter raises concerns over a lack of consistency and clarity.

The article discusses the Endorois and Southern Cameroon decisions with a particular focus on the African Commission's legal reasoning on the applicability of the peoples' rights provisions of the African Charter to particular collectives. These decisions are analysed against the backdrop of the work of the African Commission over the last two decades in promoting the recognition and protection of indigenous peoples' rights within African states. Moreover, the analysis builds on the available rich body of literature on the contentious meaning of people(s) under international law and, specifically, under the African Charter. 5 The inquiry examines the legal reasoning in Endorois and Southern Cameroon and goes beyond positivistic arguments by digging into the socio-historical and political realities underpinning the legal contentions adjudicated by African Commission in the two cases.

1 OAU Doc CAB/LEG/67/3 Rev 5; reprinted in CHeyns \& M Killander (eds) Compendium of key human rights documents of the African Union (2013) 29.

2 (2009) AHRLR 9 (ACHPR 2009) (Southern Cameroon case).

3 Centre for Minority Rights Development \& Others $v$ Kenya (2009) AHRLR 75 (ACHPR 2009) (Endorois case).

4 For some relevant analyses of the decision, see $K$ Sing'Oei 'Engaging the Leviathan: National development, corporate globalisation and the Endorois' quest to recover their herding grounds' (2011) 18 International Journal on Minority and Group Rights 515; G Lynch 'Becoming indigenous in the pursuit of justice: The African Commission on Human and Peoples' Rights and the Endorois' (2012) 111 African Affairs 24. 


\section{Peoples' rights as indigenous rights in the Endorois case}

\subsection{Facts of Endorois in a nutshell}

The Endorois case before the African Commission dealt with the eviction (the Kenyan government refers to relocation) of some 400 Endorois families from the area around Lake Bogoria (formerly Lake Hannington), after the area was gazetted in 1973 as a national park. In negotiating the resettlement process, the Kenyan authorities promised fertile lands to resettled families, compensation and a share of revenues and jobs generated by the game reserve. The Kenyan Wildlife Service - the authority directly responsible for the relocation also promised 3150 Kenyan Shillings (around 30 British pounds at the time) per family for the resettlement, but only 170 allegedly received the money. ${ }^{6}$ The petition was presented in the name of not only the 400 expelled families, but the entire Endorois community, and claimed to represent some 60000 people. ${ }^{7}$ Since their eviction, members of the affected community had unsuccessfully initiated numerous actions aimed at seeking redress for their loss. They appealed to Kenyan authorities, including to then President Daniel Arap Moi, and, as political remedies proved unsuccessful, equally unsuccessful legal actions were initiated in Kenyan courts. More than three decades after the gazetting of their lands, the legal contentions over the eviction of members of the Endorois community were submitted on their behalf to the African Commission.

\subsection{Collective identity of the Endorois}

The communication was presented on behalf of the Endorois community by the Nairobi-based Centre for Minority Rights Development (CEMIRIDE) and London-based Minority Rights Group International (MRG). The applicants alleged violations of several provisions of the African Charter guaranteeing collective rights or individual rights with a collective dimension, including the right to practise religion (article 8 ); the rights to property (article 14); to culture (article 17(2)(3)); the right to free disposition of natural resources (article 21); and the right to development (article 22). In

5 For some relevant literature, see RN Kiwanuka 'The meaning of "people" in the African Charter on Human and Peoples' Rights' (1988) 82 The American Journal of International Law 80; K M'Baye Les Droits de I'Homme en Afrique (1992) 183; UO Umozurike The African Charter on Human and Peoples' Rights (1997) 52; F Ouguergouz La Charte Africaine des Droits de I'Homme et des Peuples: Une approche juridique des droits de I'homme entre tradition et modernité (1993) 131; P Alston 'Peoples' rights: Their rise and fall' in P Alston (ed) Peoples' rights (2001) 127; J Donnelly 'Third generation rights' in C Brölmann et al (eds) Peoples and minorities in international law (1993) 119. See also F Viljoen International law in Africa (2012) 219.

6 Endorois (n 3 above) paras 7-8 \& 110.

7 Endorois paras 3-8. 
their submissions, the applicants ingeniously supported their case under the African Charter with relevant African Commission jurisprudence. Using the generous permissibility under the African Charter system to draw inspiration from domestic, regional and international human rights law and jurisprudence in interpreting African Charter provisions, they invoked numerous landmark rulings on indigenous collective rights. ${ }^{8}$ Since the Endorois represent one among more than two dozen communities in Kenya claiming an indigenous status, ${ }^{9}$ the African Commission specifically elaborated on regional, international and domestic rulings of relevance to indigenous rights.

\subsubsection{The Endorois as a(n indigenous) people}

In examining the merits of the case, the African Commission found that the Endorois constituted a people, an indigenous people, and were entitled to invoke the collective rights provisions of the African Charter. ${ }^{10}$ The legal reasoning over the Endorois as an indigenous people betrays an ambiguous marriage between the interpretative and the promotional mandates of the African Commission. The unequivocal application of peoplehood and indigenousness to the Endorois raised questions that remained unanswered in the decision. To avoid reductionist or essentialist constructions of the Endorois identity, one needs to contextually examine their claims against the backdrop of socio-political and historical dynamics in colonial and post-colonial Kenya.

The lack of terminological uniformity in references to the Endorois, the Tugen and the Kalenjin throughout the African Commission's decision displays either a disregard for the historicity of these collective attributes, or a lack of analytical and terminological rigor. The Endorois are described in some sections of the communication as a 'clan' of the Tugen (sometimes Tungen ${ }^{11}$ ) 'sub-tribe', which itself is part of the Kalenjin 'tribe'. ${ }^{12}$ However, elsewhere the communication refers to the Endorois as a sub-tribe or a clan of the Tugen tribe. ${ }^{13}$ Hence, while the term 'clan' is used only in reference to the Endorois; 'sub-tribe' is used for both the Endorois and the Tugen. ${ }^{14}$ The same applies to the concept of tribe, used in reference to both the Tugen and the Kalenjin. ${ }^{15}$ Elsewhere, the Endorois decision is referred to as

8 Endorois paras 71-135.

9 Human Rights Council 'Report of the Special Rapporteur on the Situation of Human Rights and Fundamental Freedoms of Indigenous People, Rodolfo Stavenhagen: Mission to Kenya' UN Doc A/HRC/4/32/Add.3 (2007) para 5.

10 Endorois (n 3 above) paras 144-162.

11 Endorois para $159 \mathrm{n} 71,175 \& 179$.

12 Endorois paras 142, 145, $146 \& 161$.

13 Endorois paras 3(1), $140 \& 270$. Confusingly, paras 175 and 179 refer to the 'four Tungen tribes'.

14 Endorois para 270 refers to contentions by the respondent state that ' $\mathrm{t}$ ] and Koibatek Country Councils are not only representing the Endorois, but other clans of the Tugen tribe, of which the Endorois are only a clan' (my emphasis). 
'this judgment'. ${ }^{16}$ These errors and considerations clearly suggest that the deliberations about and the drafting of the Endorois decision could have received better attention.

In submissions to the African Commission, Kenya contended that the Endorois could not be regarded as a people since they were only a clan of the Tugen sub-tribe, the latter being itself part of the larger Kalenjin tribe or group. ${ }^{17}$ The state invoked linguistic and other similarities between the various clans making up the Tugen (sub-) tribe. $^{18}$ In essence, Kenyan authorities disputed the autonomous existence of the Endorois as a cultural and socio-political community distinct from the related Tugen and Kalenjin groups, and challenged the applicants to prove the contrary. Arguably, the position of the government was in line with the 1989 and 1999 official censuses that included tribal/ethnic data whereby only the Kalenjin were listed as one of more or less 43 ethnic communities constituting the population of Kenya. ${ }^{19}$ The African Commission's ruling that the Endorois constituted a distinctive identity did not answer the above, more than semantic, considerations (as will be discussed in the next section).

Moreover, the decision leaned on the subjective criteria of selfidentification by the Endorois and their relative marginality in reaching the conclusion that they were both a people and indigenous. In reaching the conclusion that the Endorois are an indigenous people, the African Commission rehearsed the mantra of indigenous collective rights norms, jurisprudence and discourses as elaborated by national and regional systems (particularly the Inter-American human rights system), and international institutions or networks. ${ }^{20}$ Since 1999, the African Commission has initiated an active campaign aimed at securing the recognition and protection of indigenous peoples' rights by African states. ${ }^{21}$ Proponents of this dynamic sought to invoke the 'peoples' rights' provisions of the African Charter in drawing the world's attention to the plight of claimant indigenous peoples. ${ }^{22}$

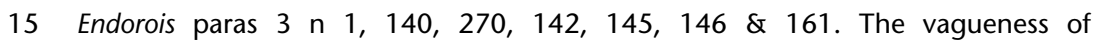
terminological usage can further be found in references to the Kalenjin group as in para $3 \mathrm{n} 1$.

16 Endorois para 203 (n 107). Judgments are rendered by courts and have a binding effect, while quasi-judicial bodies, such as the African Commission, take decisions to be implemented in good faith by state parties.

17 Endorois paras 140-142 (discrepancies in terminological use will be analysed below).

18 Endorois para 142.

19 For relevant analyses, see V Golaz 'Recensements et catégories ethniques: Les enjeux politiques de la croissance démographique kényane' (2006) 40 (3) Canadian Journal of African Studies 426; V Golaz 'Les enjeux ethniques des recensements: le recensement de 1989 au Kenya' (1997) 67 Politique Africaine 113. On Kenya's ethnic identities, see W Ng'ang'a Kenya's ethnic communities: Foundation of the nation (2006). The 2009 results of the population census with ethnic data had not yet been released at the time the case was decided.

20 In Endorois (n 3 above) paras 147-161 and 186-234, the decision extensively quotes from the Inter-American decisions on indigenous rights. For more on this, see sec 2.3.4. 
Composed essentially of members of (former) hunter-gatherers and pastoralist communities, but also some (small-scale) farmers and fishers, communities enrolled in the global indigenous movement claim historical marginality as well as an attachment to ancestral lands and lifestyles threatened by the modernisation project of the postcolonial state. The import of the indigenous rights legal framework in the African human rights regionalism, with a determinant role played by the Copenhagen-based International Work Group for Indigenous Affairs, was a result of a dynamic of globalisation of this form of identification since the early 1980s. ${ }^{23}$ The promotion of indigenous rights within African human rights regionalism became an integral part of the African Commission's agenda, ever since the establishment of its Working Group on Indigenous Populations/Communities in Africa in 2000. ${ }^{4}$

Remarkably, the indigenous rights narrative in the Endorois decision contrasts with the language of the Ogoni decision rendered in 2001 where the African Commission found violations of the applicants' collective rights as a people without any recourse to indigenous rights precepts. ${ }^{25}$ Since both groups are enrolled in the global indigenous movement ${ }^{26}$ and indigenous rights are not, after all, explicitly recognised in the African Charter, the focus on the indigenous attributes of the Endorois can only be read against the background of ongoing efforts by the African Commission to promote this particular legal framework on the continent.

\subsubsection{On the peoplehood attribute: Endorois, Tugen or Kalenjin?}

The undeniable legitimacy of the Endorois' demand for redress for land spoliation does not preclude an examination of their identity claims under the lens of identity politics in Kenya. Early colonial anthropology made limited reference to the Endorois as a specific identity. In fact, studies have struggled to clearly differentiate

21 Under art 45 of the African Charter, the African Commission is entrusted with a mission to 'promote, protect and interpret the rights in the African Charter'. For more on this, see FM Ndahinda Indigenousness in Africa: A contested legal framework for empowerment of 'marginalized' communities (2011) and relevant references therein.

22 African Commission and International Working Group for Indigenous Affairs (IWGIA) Report of the African Commission's Working Group of Experts on Indigenous Populations/Communities (2005) 72-78.

23 For an elaboration thereon, see FM Ndahinda 'Historical development of indigenous identification and rights in Africa' in R Laher \& $\mathrm{K}$ Sing'Oei (eds) Indigenous people in Africa: Contestations, empowerment and group rights (2014) 24; Ndahinda (n 21 above) 55-82.

24 African Commission 'Resolution on the Rights of Indigenous Populations/ Communities in Africa' Fourteenth Annual Activity Report (2000), African Commission/Res 51(XXVIII)00.

25 Social and Economic Rights Action Centre (SERAC) \& Another v Nigeria (2001) AHRLR 60 (ACHPR 2001) (Ogoni case).

26 As evidenced by the African Commission and IWGIA Indigenous peoples in Africa: The forgotten peoples? The African Commission's work on indigenous peoples in Africa (2006) 16. 
members of what used to be known as Nandi-speaking groups before they became "Kalenjin'. ${ }^{27}$ It is documented that "Kalenjin" is 'a corporate name for the 'Nandi-speaking tribes' ${ }^{28}$ adopted since the mid-1940s and early 1950s and popularised by elites from these communities. Prior to the adoption of the federative Kalenjin identification, studies are in many ways vague in their attempts to establish historical linkages and differences between the various 'Nandi-speaking' and, to some extent, neighbouring groups. The difficulty to delineate - territorially, linguistically and socio-politically the various sub-units of the Nandi/Kalenjin community is rooted in the inherent dynamism of identification with a particular ethnocultural community. ${ }^{29}$ More generally, relevant historical and ethnoanthropological studies have displayed the fluidity of boundaries of ethno-cultural identification. ${ }^{30}$

According to the 2009 population census, the Kalenjin are the third largest ethno-cultural group in Kenya - next to the Kikuyu and the Luhya - with a total population of 4967328 people. ${ }^{31}$ A combined reading of different sources provides the following main 'tribal' subdivisions of Kalenjin: Kipsigis (Lumbwa); Nandi (Chemgal); Tugen (Kamasia or Tuken); Marakwet (Marakweta); Keiyo (Elgeyo); Pokot (Suk); Terik (Nyangori or Elgon); Sebei (Sabaot); and Ogiek. ${ }^{32}$ These sub-units, generally referred to as Kalenjin tribes or sub-tribes, are further divided into several clans each. ${ }^{33}$ This classification is far from

27 For relevant literature, see GWB Huntingford 'Tribal names in the Nyanza and Kerio provinces, Kenya colony' (1930) 30 Man 124; JEG Sutton 'Denying history in colonial Kenya: The anthropology and archeology of GWB Huntingford and LSB Leakey' (2006) 33 History in Africa 293.

28 M Omosule 'Kalenjin: The emergence of a corporate name for the "Nandispeaking tribes" of East Africa' (1989) 27 Genève-Afrique 73.

29 See GWB Huntingford The Nandi of Kenya: Tribal control in a pastoral society (1953) 1; GWB Huntingford The Southern Nilo-Hamites (1953) 10 91; JEG Sutton 'Archeology and reconstructing history in the Kenya highlands: The intellectual legacies of GWB Huntingford and Louis SB Leakey' (2007) 34 History in Africa 297.

30 See BJ Berman 'Ethnicity, patronage and the African state: The politics of uncivil nationalism' (1998) 97 African Affairs 305; R Cohen 'Ethnicity: Problem and focus in anthropology' (1978) 7 Annual Review of Anthropology 379; G Weltfish 'The question of ethnic identity: An ethnohistorical approach' (1959) 6 Ethnohistory 321; D Welsh 'Ethnicity in sub-Saharan Africa' (1996) 72 International Affairs 477.

31 See the data from the Kenya National Bureau of Statistics, http://www.knbs.or.ke/ Census\%20Results/Presentation\%20by\%20Minister\%20for\%20Planning\%20re vised.pdf (accessed 2 September 2013). According to 1989 and 1999 censuses, they represented 2458000 and 3466000 people respectively. Golaz (n 19 above) 427 elaborates on the manipulation of these figures by authorities in favour of the then President Moi's Kalenjin community.

32 See http://www.kalenjin.net/newsite/index.php?option=com_content\&view=sec tion\&id=6\&Itemid=196 (accessed 7 May 2013).

33 See http://www.kalenjin.org/index.php?option=com_content\&view=section\&id= 6\&Itemid=196 (accessed 11 June 2013); S Tornay 'Le test des triades dans l'étude des nomenclatures de parenté' (1969) 39 Journal de la Société des Africanistes 84. 
authoritative: It is subject to alternative groupings or nomenclatures. ${ }^{34}$ The status of tribe or ethnicity is attributed to the Kalenjin community as a whole or to the sub-units grouped therein, depending on whether the identification stresses commonalities or differences. In 2002, Anderson deplored the fact that Kalenjin history had received 'only slight scholarly attention, and what research has been conducted has focused in the main upon Nandi and Kipsigis, with a concentration upon precolonial history ... and the impact of colonial conquest' ${ }^{35}$

As contended by Kenyan authorities before the African Commission, existing ethnographic data considers the Endorois as one of the clans of the Tugen people. ${ }^{36}$ Other Tugen clans are the Arror, the Samor(r), the Lembus and the Pokor. ${ }^{37}$ Like the Tugen, other (sub-) tribes of the Kalenjin are each equally divided into several clans and age sets. ${ }^{38}$ Generally, most of these clans or (sub-) tribes of the Kalenjin can be demarcated territorially, linguistically and, indeed, culturally. ${ }^{39}$ Yet, only some of these identities are currently more active than others in asserting their differences vis-à-vis fellow Kalenjin. For instance, alongside the Endorois, the Sabaot, the Pokot and the Ogiek are equally involved in a global indigenous rights movement that essentially advocates special protection of particular groups on grounds of differential socio-cultural characteristics. ${ }^{40}$ In an everdynamic context, like Kenya, whereby national identity, clan, subtribe, tribe or communities regrouping several tribes are all notions in constant renegotiation, a clear determination of what exact societal unit constitutes a people indigenous to a specific territory is more than challenging. ${ }^{41}$

\subsubsection{Ethnicity and indigenous identification in Kenya}

Ethnic politics have been an integral part of the Kenyan socio-political landscape since the creation of the first political organisations in the

34 See G Lynch 'Courting the Kalenjin: The failure of dynasticism and the strength of the ODM wave in Kenya's Rift Valley province' (2008) 107 African Affairs 542; JA Distefano 'The precolonial history of the Kalenjin of Kenya: A methodological comparison of linguistic and oral traditional evidence' unpublished PhD thesis, University of California/Los Angeles, 198532 et seq.

35 DM Anderson Eroding the commons: The Politics of ecology in Baringo, Kenya 18901963 (2002) 17-18.

36 Endorois (n 3 above) para 92; MO Makoloo Kenya: minorities, indigenous peoples and ethnic diversity (2005) 17; Anderson (n 35 above) 58 et seq.

37 Makoloo (n 36 above) 17.

38 See Huntingford The Southern Nilo-Hamites (n 29 above) 26; Ng'ang'a (n 19 above) 307; Anderson (n 35 above) 23.

39 Ng'ang'a (n 19 above) 307.

40 See UN Doc A/HRC/4/32/Add.3, 26 February 2007 para 5.

41 G Lynch 'Negotiating ethnicity: Identity politics in contemporary Kenya' (2006) 107 Review of African Political Economy 49. 
run-up to the country's independence. ${ }^{42}$ During the 1950 s and 1960 s, elites active in local and national politics engineered the unity of communities with ethno-cultural affinities in moves intended to boost their ethnic competitiveness at local and national stages. ${ }^{43}$ Conversely, the 1990s witnessed a 'marked tendency in Kenya for communities to emphasise the fact that they are distinct' ${ }^{44}$ In fact, members of Kalenjin communities were collectively identified or identified themselves with elites that most benefited from more than two decades of the rule of the Tugen-Kalenjin President Daniel Arap Moi from 1978 to $2002 .{ }^{45}$

The prevalence of contemporary indigenous rights activism in Kenya's Rift Valley province should be examined against the backdrop of the politics of belonging that predates the country's accession to independence. The Kalenjin-Maasai-Turkana-Samburu communities once known as Kamatusa - have aggressively used different platforms to ensure their recognition as the authentic natives of the Rift Valley. ${ }^{46}$ They have constantly portrayed members of other communities, such as the Kikuyu living in the province but whose 'homelands' are in other provinces, as invading foreigners. Before they started framing their claims using the global language of the indigenous rights struggle for survival, political elites from the Rift Valley advocated majimboism (coined from Majimbo, the Swahili word for regional administrative entities) as the appropriate 'basis for a devolved constitutional arrangement that would protect smaller "minority" communities from the dominance of larger communities' ${ }^{47}$ Majimboism did not simply promote a decentralisation of power from Nairobi to the regions, but rather some form of federalism based on ethnicity. ${ }^{48}$ The most radical consequences of the implementation of majimboism would be for 'all those who find themselves in the [regions] other than those in which their ancestors were living in 1895 when Kenya was born to return to the [regions] of their ancestors and abandon property without compensation'. ${ }^{49}$

42 DM Anderson "'Yours in struggle for Majimbo". Nationalism and the party politics of decolonisation in Kenya, 1955-64' (2005) 40 Journal of Contemporary History 547; International Crisis Group (ICG) Kenya in crisis (2008) 37.

43 See Golaz (n 19 above) 426; Golaz (n 19 above) 113; Omosule (n 28 above) 76.

44 Lynch (n 41 above) 54. See also SN Ndegwa 'Citizenship and ethnicity: An examination of two transition moments in Kenyan politics' (1997) 91 The American Political Science Review 599; JM Klopp "'Ethnic clashes" and winning elections: The case of Kenya's electoral despotism' (2001) 35 Canadian Journal of African Studies 473.

45 Anderson (n 42 above) 550; C Thomas 'Le Kenya d'une élection à l'autre Criminalisation de l'Etat et succession politique (1995-1997)' 1997) Les Etudes du CERI.

46 GK Adar 'Assessing democratisation trends in Kenya: A post-mortem of the Moi regime' (2000) 38 Commonwealth and Comparative Politics 117; Ndegwa (n 44 above) 599.

47 Anderson (n 42 above) 547.

48 L Hughes 'Malice in Maasailand: The historical roots of current political struggles' (2005) 104 African Affairs 215. 
Since the Kenyan struggle for independence, political debates have been characterised by a constant quest for a suitable constitutionalism. ${ }^{50}$ National political processes have been described as having undergone phases of 'Africanisation', 'Kenyanisation' (known also as 'Kikuyunisation') and 'Kalenjinisation'. 51 The lack of coherence, inclusiveness and accountability has somehow resulted in an institutionalisation of ethnicity as a legitimate source of representation. ${ }^{52}$ After half a century of failed attempts to institute a state structure consisting of a federation of ethnicities, Rift Valley political operatives have found in the indigenous rights framework a powerful source of legitimacy in their efforts to shelter 'ancestral territories' against perceived invasions from members of non-native communities. The perceived lack of sufficient protection against invasions by members of other groups, coupled with ethnic politics, were the main grounds for the negative vote of all the Kalenjindominated constituencies on the proposed Kenyan Constitution backed by 67 per cent of the national population during the 4 August 2010 referendum. ${ }^{53}$

\subsection{Substantive violations of the Endorois' rights by Kenya}

\subsubsection{Temporal applicability of the African Charter}

The African Commission found violations of all provisions invoked by the applicants. Since the communication invoked violations that took place over a long period of time, starting from a time before the entry into force of the African Charter, the African Commission needed to address the temporal applicability of the instrument. Central to the applicants' case was the eviction from ancestral lands around Lake Bogoria since the 1973 gazetting of the area as a game reserve. ${ }^{54}$ The sequence of facts as summarised in the communication focuses on the adverse consequences of the creation of the Lake Bogoria Game Reserve for the Endorois community. The applicants further extended

49 Ndegwa (n 44 above) 611, quoting the Citizens Coalition for Constitutional Change Circa 1995. Summary of the Report of Caucus $I$.

50 Klopp (n 44 above) 473; Ndegwa (n 44 above) 599.

51 Makoloo (n 36 above) 25. See also D Rothchild 'Kenya's Africanisation programme: Priorities of development and equity' (1970) 64 The American Political Science Review 737; R Southall \& G Wood 'Local government and the return to multi-partyism in Kenya' (1996) 95 African Affairs 501.

52 See UN Doc A/HRC/4/32/Add.3 26 February 2007, paras 21-22, whereby communities complained to the UN Special Rapporteur on Indigenous Rights that they lacked political representation due to a dispersed habitat across different administrative and electoral units.

53 For more on this, see http://www.bbc.co.uk/news/world-africa-10876635 (accessed 6 September 2013) and M Mutua 'Why the tribe could kill the constitution' Daily Nation 4 September 2010.

Endorois (n 3 above) paras 2-3. 
their claims for redress to their eviction from the Mochongoi forest. ${ }^{55}$ The Kenyan government argued that the eviction from the Mochongoi forest - renamed Ol Arabel forest ${ }^{56}$ - took place in 1941 under colonial administration. ${ }^{57}$ The Kenyan authorities further contended that this particular claim was not part of the issues addressed by domestic courts and could, therefore, not be addressed in first instance by the African Commission. ${ }^{58}$

The Commission agreed with the applicants that 'Lake Bogoria and the Monchongoi [sic] forest are central to the Endorois' way of life and, without access to their ancestral land, the Endorois are unable to fully exercise their cultural and religious rights, and feel disconnected from their land and ancestors' ${ }^{59}$ The African Commission decision requested the Kenyan government, among others, to (a) recognise the Endorois' ownership of, and restitute, their ancestral land; and (b) grant them 'unrestricted access to Lake Bogoria and surrounding sites for religious and cultural rites and for grazing their cattle' ${ }^{60}$

Clearly, the acts of eviction, the non-payment of adequate compensation and initial restrictions to access to or use of the gazetted areas surrounding Lake Bogoria took place before 1992 when the African Charter entered into force for Kenya following its ratification of the instrument. Undoubtedly, the various restrictions to access to or use of ancestral lands adversely affected and continue to affect the Endorois and might, arguably, be interpreted as constitutive of 'continuous violations'. ${ }^{61}$ However, a closer examination of the case and of the decision shows that the awarded remedy (land restitution, the recognition of land ownership and unrestricted access to ancestral land) challenges acts that mainly took place prior to the entry in force of the African Charter. A revealing example is the African Commission's finding under article 8 of the African Charter that the forced eviction of the Endorois from ancestral lands constituted a violation of their right to religious freedom, ${ }^{62}$ despite the fact that the actual act of eviction was completed by the time of the entry in force of the African Charter. ${ }^{63}$

55 In the African Commission decision, the name of the forest is spelt as Mochongoi (paras 77, 78, 132, 143, 167, 182, 223, 226 \& 297); Monchongoi (paras 6, 73, $74 \& 156)$ or Muchongoi (paras $179 \&$ nd 223).

56 Endorois (n 3 above) paras 143, 179, $180 \& 223$.

57 Endorois paras 179\& 182.

58 Endorois paras 105-112, 175-177, $203 \& 224$.

59 Endorois para 156.

60 Endorois para 298(b).

61 On temporal applicability of the African Charter and an interesting case submitted to the African Commission by an applicant from Kenya ruled inadmissible for invoking violations that took place prior to the entry into force of the instrument, see F Viljoen, 'Admissibility under the African Charter' in MD Evans \& R Murray (eds) The African Charter on Human and Peoples' Rights: The system in practice, 1986-2000 (2002) 76-77.

62 Endorois (n 3 above) para 173.

63 Endorois paras 3-11 \& 19. 
The theory of applicability of the African Charter to continuous violations does not explain how the instrument can be used retrospectively to determine violations of an instrument not in force at the time of the facts. The decision suggests that it is possible to invoke the protective mandate of the African Charter in respect of facts that took place any time in the past, as long as one proves that they have contemporary repercussions that may be interpreted as (continuous) violations of the instrument. As far as the applicability of the African Charter is concerned, there appears to be no difference between the eviction of the Endorois by Kenyan authorities since the 1970s and the Maasai moves by British authorities at the beginning of the twentieth century, since the latter are still central to contemporary indigenous discourses of the Maasai in Kenya. ${ }^{64}$ If the latter were to be considered as continuous violations of the African Charter, there would be virtually no temporal limits to the notion of continuous violations, as the list of historical wrongs with contemporary repercussions is potentially endless.

\subsubsection{Freedom of religion and the Endorois' beliefs}

The African Commission relied on submissions by, and testimony of, the applicants in finding a violation of their freedom of religion through a denial of access to the reserve. ${ }^{65}$ It failed to elaborate on the contemporary significance of the Endorois' traditional religious practices. More specifically, the religious dimension of rituals such as circumcision, marriage and initiation is not self-evident. In spite of local variants, many traditional African societies hold these customary rituals. $^{66}$ The commendably broad interpretation of freedom of religion by the African Commission was nonetheless unconvincingly applied to the Endorois case. Since the pre-colonial, but mostly during the colonial and post-colonial eras, many African societies have adhered to institutionalised religions originating from other continents, such as Christianity and Islam. ${ }^{67}$ The domestication of these other forms of beliefs in some cases tolerated the subsistence of traditional beliefs but, in many others, was accompanied by the

64 On the Maasai moves, see L Hughes Moving the Maasai: A colonial misadventure (2006).

65 Endorois (n 3 above) para 173.

66 See WA Norton 'Customs of Central and South Africa: Some notes and comparisons' (1914) 14 Journal of the Royal African Society 81-87; EK Silverman 'Anthropology and circumcision' (2004) 33 Annual Review of Anthropology 419; GWB Huntingford 'Miscellaneous records relating to the Nandi and Kony tribes' (1927) 57 The Journal of the Royal Anthropological Institute of Great Britain and Ireland 417.

67 For some relevant literature, see AA Weinreb 'First politics, then culture: Accounting for ethnic differences in demographic behaviour in Kenya' (2001) 27 opulation and Development Review 437. 
erosion of the latter. ${ }^{68}$ Accordingly, these considerations should have dictated a deeper examination by the African Commission of the contemporaneous reality of the Endorois community's traditional practices, their religious character and the sacredness of reserve sites. Such in-depth examination is even more vital in light of the retreating boundaries between myth and reality in reconstructions of the Endorois' historical settlement around Lake Bogoria. ${ }^{69}$

\subsubsection{Land and cultural rights of the Endorois}

Land rights are central to the communication since, besides compensation for their losses, the applicants before the African Commission primarily sought the restitution of their land, 'with title and clear demarcation'. 70 The Commission found that the eviction of the Endorois and the denial of their access to ancestral land represented violations of both relevant Kenyan laws and the applicable provisions of the African Charter relating to land rights. Under Kenyan law applicable at the time of the eviction, the land occupied by the Endorois was considered as trust land and administered by the Baringo and Koibatek County Councils for the benefit of the traditional occupants. ${ }^{71}$ The facts of the case clearly show that the Kenyan authorities did not comply with established procedures for the alienation of trust land, namely, registration to a person other than the County Council or an Act of Parliament providing for the County Council to set apart an area of trust land, ${ }^{72}$ and full compensation of the affected persons. ${ }^{73}$ Drawing from the facts of the case, it was argued - and not disputed - by the respondent that the land was not formally set apart before gazetting. ${ }^{74}$ Moreover, the African Commission rightly found that the payment of some 3150 Kshs to only 170 of the 400 evicted families some 13 years after the eviction could not be considered appropriate compensation. ${ }^{75}$

Provisions of Kenyan law on trust land invoked by applicants referred to occupation of, rather than right to property over, the land. The trust land was administered by the Council for the benefit of the persons ordinarily resident on that land (in this case the Endorois). ${ }^{76}$ Rather than being mere beneficiaries, the African Commission determined that the Endorois enjoyed a property right over ancestral

68 See M Wright 'African history in the 1960s: Religion' (1971) 14 African Studies Review 439 for an early overview of literature on religion in Africa.

69 See Anderson (n 35 above) 299.

70 Endorois (n 3 above) para 22.

71 Endorois paras 88 \& 103-108.

72 Endorois paras $69 \& 105-108$.

73 Endorois para 105 ( $\mathrm{n} 82$ ) on legal requirements for setting apart the land.

74 Endorois paras 177, 178 \& 224.

75 Endorois para 230.

76 Endorois para 88. 
lands prior to their eviction. ${ }^{77}$ It further determined that, even after the eviction in blatant violation of applicable Kenyan and international legal standards, the land never ceased to be the property of the Endorois. $^{78}$

Another provision invoked by applicants - article 17(2) of the African Charter - provides for the freedom of individuals to participate in the cultural life of the community to which they belong, while article 17(3) of the Charter imposes a duty on states to promote and protect the morals and traditional values recognised by the community. In the Endorois decision, culture was defined as 'the sum total of the material and spiritual activities and products of a given social group that distinguish it from other similar groups' ${ }^{79}$ Since the African Commission had already determined in preceding paragraphs that the Endorois constituted a distinct, indigenous people, it reached the following conclusion under articles 17(2) and (3): ${ }^{80}$

By forcing the community to live on semi-arid lands without access to medicinal salt licks and other vital resources for the health of their livestock, the Respondent State have [sic] created a major threat to the Endorois' pastoralist way of life. It is of the view that the very essence of the Endorois' right to culture has been denied, rendering the right, to all intents and purposes, illusory.

The correlation between culture and pastoralism as the way of life of the Endorois is clearly inspired by the work of the African Commission and, mostly, the International Working Group for Indigenous Affairs (IWGIA) whose 2005 joint report on Indigenous Populations/ Communities listed communities historically characterised by primary reliance on hunting-gathering and pastoralist lifestyles. ${ }^{81}$ Historical and anthropological research on 'fundamentally' pastoralist East African communities - including the Kalenjin - suggests that for ages many of them had adhered to mixed modes of production combining pastoralism with agriculture. ${ }^{82}$ In fact, the African Commission's decision in the Endorois case referred to the applicants' claim that, for centuries, the community had 'constructed homes on the land, cultivated the land, enjoyed unchallenged rights to pasture, grazing, and forest land, and relied on the land to sustain their livelihoods' ${ }^{83}$ The analysis lacks some depth in creating a link between the sole pastoralist mode of production and a violation of the freedom to participate in the cultural life of the community. Since the forced

77 Endorois para 184.

78 Endorois para 209.

79 Endorois para 241.

80 Endorois para 251.

81 See more generally African Commission and IWGIA (n 22 above).

82 See R Mace et al 'Transitions between cultivation and pastoralism in sub-Saharan Africa' (1993) 34 Current Anthropology 363; HK Schneider et al 'Economic development and economic change: The case of East African cattle' (1974) 15 Current Anthropology 259.

83 Endorois (n 3 above) para184 (my emphasis). See similar references in paras 87 and 189. 
removal from fertile lands to semi-arid areas deprived the applicants of lands suitable for cultivation, one wonders whether this also constitutes a violation of the right to participate in the cultural life of the community.

\subsubsection{Control of natural resources and the right to development}

The African Commission invoked its jurisprudence in Ogoni in finding a violation of article 21 of the African Charter on the right of peoples to 'freely dispose of their wealth and natural resources'. The Commission reached a positive finding of a violation of article 21 of the African Charter. Relying on relevant case law of the Inter-American Court of Human Rights (Inter-American Court) interpreting the right to property, ${ }^{84}$ it concurred with the latter that the right of indigenous or tribal communities over traditionally-used and occupied lands covers traditionally-used natural resources essential for the survival of members of that community. ${ }^{85}$

The decision in the Endorois case has also been hailed for the positive finding of a violation of the right to development. ${ }^{86}$ The African Commission lamented the fact that evicted families were not compensated with other suitable lands for grazing and that the resulting exploitation of their lands affected their access to clean water. ${ }^{8}$ In reaching this finding, the Commission underscored the lack of effective consultation with and participation by the Endorois in the process of establishment, as well as in the management of the game reserve. ${ }^{88}$ The examination of the violation of the right to development of the Endorois revolved around references to doctrinal and jurisprudential interpretation of the requirement for governments to obtain free, prior and informed consent of indigenous peoples before taking important decisions affecting their lives, and around the precariousness of their living conditions after the resettlement on

84 Endorois paras 257-266. Invoked cases of the Inter-American Court are Case of the Saramaka People $v$ Suriname (28 November 2007); Sawhoyamaxa Indigenous Community $v$ Paraguay (29 March 2006) and Case of Yakye Axa Indigenous Community $v$ Paraguay (17 June 2005). The tremendous influence of the jurisprudence of the Inter-American Court is exemplified by the fact that 'Saramaka(s)' appears 71 times in the decision and, in some cases, numerous paragraphs (257-266) are dedicated to the case.

85 Endorois (n 3 above) para 260.

86 Human Rights Watch 'Kenya: Landmark ruling on indigenous land rights' 4 February 2010, http://www.hrw.org/en/news/2010/02/04/kenya-landmarkruling-indigenous-land-rights (accessed 7 July 2015). The author celebrates the 'first ruling of an international tribunal' on this particular right. The African Commission is neither a tribunal nor was it making a finding for the first time of a violation of the right to development since such a finding was made in Democratic Republic of the Congo v Burundi, Rwanda and Uganda (2004) AHRLR 19 (ACHPR 2004) para 95.

87 Endorois (n 3 above) para 288.

88 Endorois paras 279-281, $289 \& 297$. 
inhospitable lands. ${ }^{89}$ Moreover, a violation of the Endorois' right to development is inferred from community deprivation as a result of the eviction, and the lack of fair compensatory alternatives offered by the government. The African Commission found that the Kenyan state did not fulfil its obligation of creating favourable conditions for the Endorois' development. ${ }^{90}$

\section{Secession and self-determination of Southern Cameroon}

\subsection{Contentious decolonisation of Northern and Southern Cameroon}

The root causes of the Southern Cameroonians' attempts to secede from the Republic of Cameroon epitomise the identity crisis of more than one African state. ${ }^{91}$ The Kamerun Protectorate became a German possession upon the partition of Africa during the Berlin Conference in 1884-1885. ${ }^{92}$ Article 119 of the Covenant of the League of Nations dictated that defeated Germany had to renounce all 'rights and titles over her overseas possessions', 93 including the Kamerun Protectorate. The territory was divided into French and British possessions administered under the mandate system of the League of Nations and, later, the trusteeship system of the United Nations (UN). ${ }^{94}$ The larger part of the partitioned territory, French Cameroon, was 'incorporated into the French colonial empire as a distinct administrative unit separate from neighbouring French Equatorial Africa' ${ }^{95}$ The Northern and Southern Cameroon territories, administered by Britain, consisted of 'two narrow non-contiguous

89 Endorois paras $279 \& 290$ (where the African Commission deplored the fact that ' $\mathrm{t}$ ] he respondent state did not obtain the prior, informed consent of all the Endorois before designating their land as a game reserve and commencing their eviction'); 291, 293 \& 296.

90 Endorois para 298. On the substance of the right to development, see A Sengupta 'On the theory and practice of the right to development' (2002) 24 Human Rights Quarterly 837; P Alston 'Making space for new human rights: The case of the right to development' (1988) 1 Harvard Human Rights Yearbook 3.

91 See A Hughes 'Decolonising Africa: Colonial boundaries and the crisis of the (non) nation state' (2004) 15 Diplomacy and Statecraft 833.

92 P Konings 'The Anglophone Cameroon-Nigeria boundary: Opportunities and conflicts' (2005) 104 African Affairs 278.

93 Covenant of the League of Nations (Versailles Treaty, 28 June 1919), LNTS Vol 1, Geneva 1920.

94 As above. See also AA McPheeters 'British Cameroons development program and self-determination' (1960) 21 Phylon 367.

95 Konings (n 92 above) 278. 
regions bordering Nigeria and stretching from the Atlantic coast to Lake Chad'. 96

Contemporary politics of secession by Southern Cameroon are rooted in administrative structures instituted during roughly three decades of British rule over the territory. The French-administered Cameroon gained independence on 1 January 1960 as La République du Cameroun (as often referred to by Southern Cameroonian activists to stress its French roots). ${ }^{97}$ In the same year, the neighbouring British colony and protectorate of Nigeria achieved independence on 1 October 1960 and adopted a federal structure. Two UN-supervised plebiscites were conducted in Northern Cameroon on 11-12 February 1961 and in Southern Cameroon on 1 October 1961 to determine the decolonisation fate of these territories. ${ }^{98}$ These referenda resulted in a choice by a substantial majority of the people of Northern Cameroon to 'achieve independence by joining the independent Federation of Nigeria', 99 while the people of Southern Cameroon decided to join the Republic of Cameroon. The Republic of Cameroon petitioned the International Court of Justice (ICJ), challenging the validity of the process of decolonisation of Northern Cameroon. ${ }^{-100}$ It claimed to have suffered an injustice as a result of 'the attachment of the northern part of Cameroons to a state other than the Republic of Cameroon'. ${ }^{101}$ However, since the application did not pursue the invalidation of the result of the plebiscite by either the IC], the United Kingdom or Nigeria, or that the UN could be held responsible at the time of the application for a violation of a trusteeship agreement that had ceased to exist, the case was somewhat inconclusive.

The dynamics that followed the reunification of Southern Cameroon with the Republic of Cameroon are central to the Anglophone-Francophone divide. ${ }^{102}$ Advocates for autonomy or secession of Southern Cameroon retrospectively denounce the

96 As above. See also Case concerning the Northern Cameroons (Cameroon v United Kingdom), Preliminary Objections ICJ (2 December 1963) (1963) ICJ Reports 21; JR Stevenson 'Case concerning the Northern Cameroons (Cameroon $v$ United Kingdom), Preliminary Objections' (1964) 58 American Journal of International Law 489.

97 Stevenson (n 96 above) 489-490. See also http://www.southerncameroonsig.org/ (accessed 13 July 2014) Southern Cameroons claims.

98 Northern Cameroons case (n 96 above) 21. See also B Flemming 'Case concerning the Northern Cameroons (Cameroon v United Kingdom), Preliminary Objections' (1964) 2 Canadian Yearbook of International Law 215.

99 United Nations General Assembly 'The future of the trust territory of the Cameroons under the United Kingdom administration' GA Res 1608 (XV), UN GAOR, 994th plenary meeting 21 April 1961 para 2(a).

100 Northern Cameroons case (n 96 above) 15-40. See also DHN Johnson 'The Case Concerning the Northern Cameroons' (1964) 13 International and Comparative Law Quarterly 1143.

101 Northern Cameroons case 32.

102 See P Konings \& FB Nyamnjoh 'The Anglophone problem in Cameroon' (1997) 35 The Journal of Modern African Studies 207. 
reunification process. ${ }^{103}$ Stark claims that feelings of marginality of Southern Cameroon within the Nigerian federation prior to the plebiscites and resentment against economic dominance of Igbos were instrumental in the choice to join the Republic of Cameroon. 104 The initial association of the two territories took the form of a federal republic consisting of two states, known as West Cameroon and East Cameroon. ${ }^{105}$ The political leadership of the French-speaking Republic of Cameroon manoeuvred to abolish the federal structure and achieved this through a controversial national referendum held on 20 May 1972. ${ }^{106}$ Under an administrative remapping of the territory still in place, the former territory of Southern Cameroon covers the southwest and northwest provinces of a unitary Cameroonian state. ${ }^{107}$

Advocates for autonomy or independence of Southern Cameroon argue that, under President Ahidjo, their region was subjugated by linguistically Francophones, regionally northerners, religiously Muslim and ethnically Fulani elites. 108 After President Ahidjo was succeeded in November 1982 by Paul Biya - from the mainly Christian centralsouthern part of former French Cameroon - 'the political and cultural rights of the Anglophones were not restored'. ${ }^{109}$ The Anglophones' political activism for independent statehood took shape in the 1980s, but their demands were ignored and some of the activists - such as Fon Gorji Dinka - harshly repressed. ${ }^{110}$ Their political struggle gained visibility and intensity when the country initiated a process of political liberalisation following geopolitical changes and a democratisation process that accompanied the fall of the Berlin Wall in $1989 .^{111}$ Their recriminations against the Republic of Cameroon - listed in the 2-3 April 1993 Buea Declaration - revolved around violations of the terms of reunification and the socio-political and economic

$103 \mathrm{C}$ Anyangwe Imperialistic politics in Cameroon: Resistance and the inception of the restoration of the statehood of Southern Cameroons (2008) 33 http:// southerncameroonsig.typepad.com/ig/2005/07/African Commission_communica. html\#more (accessed 14 July 2014). See also Konings \& Nyamnjoh (n 102 above) 207; NF Awasom 'Negotiating federalism: How ready were Cameroonian leaders before the February 1961 United Nations Plebiscites?' (2002) 36 Canadian Journal of African Studies 425.

104 FM Stark 'Federalism in Cameroon: The shadow and the reality' (1976) 10 Canadian Journal of African Studies 425.

105 Stark (n 104 above) 423.

106 Stark 440.

107 D Eyoh 'Conflicting narratives of Anglophone protest and the politics of identity in Cameroon' (1998) 16 Journal of Contemporary African Studies 249.

108 Anyangwe (n 103 above) 34; Eyoh (n 107 above) 255-257; E Anyefru 'Paradoxes of internationalisation of the Anglophone problem in Cameroon' (2010) 28 Journal of Contemporary African Studies 85; Konings \& Nyamnjoh (n 102 above) 211.

109 Hughes (n 91 above) 857; M Krieger 'Cameroon's democratic crossroads, 1990-4' (1994) 32 Journal of Modern African Studies 606.

110 E Anyefru 'Cyber-nationalism: The imagined Anglophone Cameroon community in cyberspace' (2008) 6 African Identities 257.

111 See Anyefru (n 108 above) 86; Konings \& Nyamnjoh (n 102 above) 211. 
marginalisation of Southern Cameroon. ${ }^{112}$ Demands shifted from increased political participation to autonomy and, eventually, independence. ${ }^{113}$ An organisation called Southern Cameroon National Council held a contested 'signature referendum' in September 1995 which overwhelmingly supported the independence of the territory. ${ }^{114}$ Some four years later, on 30 December 1999, the organisation proclaimed 'the revival of the independence and sovereignty of the Southern Cameroons' ${ }^{115}$ Complementarily to their political activism, judicial institutions were also seized of adjudicating claims for autonomy or independence.

\subsection{Judicial quest for recognition of Southern Cameroon's independence}

\subsubsection{Proceedings before the Nigerian High Court}

In February 2002, Kevin Ngwang Gunme and 11 others took their case for self-determination and independence before the Federal High Court of Nigeria in Abuja. ${ }^{116}$ In justification of their rather peculiar case before a Nigerian Court, the applicants invoked articles 1 and 20 of the African Charter (respectively on the undertaking to give effect to rights, freedoms and duties enshrined in the Charter and on the right to self-determination) and article 2(3) of the Charter of the United Nations (UN) (on peaceful resolution of disputes). Following an elaborate enumeration of violations of their rights by the Republic of Cameroon, the applicants requested the Court to (i) declare and order that Nigeria has - and should exercise - a legal duty to place before the ICJ and the United Nations General Assembly (UNGA) and to ensure diligent prosecution to conclusion, the claim of the people of Southern Cameroon to self-determination and their declaration of independence; (ii) issue a perpetual injunction restraining Nigerian officials from treating or continuing to treat Southern Cameroon as part of the Republic of Cameroon. ${ }^{117}$ The Court made a positive ruling on the admissibility of the case. ${ }^{118}$ However, proceedings were stayed following an agreement between the parties that the Federal

112 Anyefru (n 108 above) 88.

113 Anyefru 87-88. See also L Sindjoun 'Le champ Social Camerounais: Désordre Inventif, Mythes Simplificateurs et Stabilité Hégémonique de l'État' (1996) 62 Politique Africaine 64.

114 Southern Cameroon (n 2 above) (Submissions by Applicants in Communication 266/2003, Submissions by the Applicants, para 139; http://southerncameroon sig.typepad.com/ ig/images/African Commission.pdf (accessed 15 July 2010).

115 Southern Cameroon paras 119-120.

116 Gunme \& Others $v$ Attorney-General of the Federal Republic of Nigeria, Suit FHC/ABJ/ CS/30/2002, Ruling of 5 March 2002, http://southerncameroonsig.typepad.com/ abuja.pdf (accessed 14 July 2013) 2.

117 Southern Cameroon (n 2 above) paras 59-65. See also N Enonchong 'Foreign state assistance in enforcing the right to self-determination under the African Charter: Gunme (sic) \& Others v Nigeria' (2002) 46 Journal of African Law 246 et seq.

118 Gunme \& Others $v$ Attorney-General of the Federal Republic of Nigeria (5 March 2002), Enrolment of Order 13. 
Republic of Nigeria shall (i) institute a case before the ICJ on the regularity of the termination of the United Kingdom trusteeship over Southern Cameroon and the ensuing reunification with the Republic of Cameroon; and (ii) shall take any other measures as may be necessary to place the case of the people of Southern Cameroon for self-determination before the UN General Assembly and any other relevant international organisations. ${ }^{119}$ More than a decade later, there appears to be no evidence that Nigeria followed up on its promise. Less than one year after the ruling by the Federal High Court of Nigeria in Abuja, the case for self-determination and independence of Southern Cameroon was taken before the African Commission.

\subsubsection{The Southern Cameroon case before the African Commission}

On 9 January 2003, Kevin Mgwanga Gunme and 13 others filed a complaint before the African Commission against the Republic of Cameroon alleging that, for decades, the inhabitants of Southern Cameroon were the victims of discrimination, socio-political and economic marginalisation as well as the denial of the right to selfdetermination and independent statehood. ${ }^{120}$ Before examining the substance of the African Commission's decision in the case, a few details are worth mentioning. First, the title of the decision refers to the communication as Kevin Mgwanga Gunme et al $v$ Cameroon, in reference to the first listed name of the 14 applicants. However, the text of the Submissions by the Applicants in Communication 266/ 2003 to the African Commission refers to Dr Kevin Ngwang Gumne. ${ }^{121}$ It is not quite clear how Ngwang Gumne in the complaint became Mgwanga Gunme in the decision. Second, the decision by the African Commission repeatedly refers to 'Southern Cameroon' (without ' $s$ ') while the official name of the territory as reproduced in the petitioners' complaint and other sources is 'Southern Cameroons'. ${ }^{122}$

As in the case before the Federal High Court of Nigeria in Abuja, the applicants presented the case on behalf of the entire population of Southern Cameroon, claimed to represent six million people. ${ }^{123}$ In support of their case for independence, they invoked violations by the Cameroonian state of several provisions of the African Charter. ${ }^{124}$ Under articles 19 and 20 of the African Charter - freedom from

119 As above.

120 Southern Cameroon (n 2 above) paras 1-20.

121 See Dr Gunme \& Members of the SCNC and SCAPO v Cameroon, Communication 266/2003, Submissions by the Applicants, para 139, http://southern cameroonsig.typepad.com/ig/images/African Commission.pdf (accessed 15 July 2013).

122 See eg Southern Cameroon (n 2 above) paras 1, 2, 3, 4, 5 \& 6.

123 Southern Cameroon para 4. Eyoh (n 107 above) 268 claimed (in 1998) that the north west and south west provinces of Cameroon were inhabited by 1237400 and 830000 people respectively. If these figures were accurate, a population of six million in 2003 when the application was filed before the African Commission would mean that, in just five years, the population had tripled. 
domination, peoples' rights to self-determination and the rights of colonised people to break the chains of their subjugation - the applicants characterised Cameroonian rule over Southern Cameroon as a 'forceful annexation'125 or an 'occupation and assumption of a colonial sovereignty'. ${ }^{126}$ They contended: ${ }^{127}$

The Southern Cameroons was ... under British rule from 1858 to 1887, and then from 1915 to 1961, a total period of nearly 80 years. That long British connection left an indelible mark on the territory, bequeathing to it an Anglo-Saxon heritage. The territory's official language is English. Its educational, legal, administrative, political, governance and institutional culture and value systems are all English-derived.

From the above quotation, it is clear that the applicants before the African Commission built their case for independence around a purported 'cultural distinctiveness', arising from a shared colonial experience rather than a common historical identity pre-dating German and British colonisation. It is a fact that the territory formerly known as Southern Cameroons is inhabited by dozens of ethnic communities that were not politically united prior to their colonial subjugation by Germany and Britain. ${ }^{128}$ In the words of Konings and Nyamnjoh, quoting Sindjoun: ${ }^{129}$

Anglophone identity can actually only be claimed by inhabitants belonging to one of the territory's 'autochthonous' ethnic groups, a distinction which tends to exclude immigrants from Southern Cameroons citizenship ... and which makes being 'anglophone' more of a geographic and administrative reality than a cultural one.

\subsubsection{Legal findings of the African Commission}

The African Commission found numerous violations of the African Charter by the Republic of Cameroon. The refusal to register companies established by Southern Cameroonians on account of language was found to be a violation of article 2 of the African Charter prohibiting discrimination. ${ }^{130}$ The African Commission held that killings by the police during violent suppressions of peaceful demonstrations and deaths in detention as a result of the bad conditions or ill-treatment in prisons constituted violations of article 4 of the African Charter on the right to life, the inviolability of the

124 Southern Cameroon para 19. The applicants invoked violations of articles 2, 3, 4, 5, $6,7(1), 9,10,11,12,13,17(1), 19,20,21,22,23(1), 24$ and 26 of the African Charter.

125 Southern Cameroon paras 6, 7, $73 \& 151$.

126 Southern Cameroon para 152.

127 Submissions by Applicants in Communication 266/2003, para 11.

128 As rightly noted in VT le Vine The Cameroon Federal Republic (1971) 45, there are no updated censuses - and, thus, no authoritative sources - documenting ethnolinguistic groups in Cameroon. However, the author suggested that there were 'more than 136 identifiable linguistic groupings in East Cameroon and about 100 vernaculars in West Cameroon'.

129 Konings \& Nyamnjoh (n 102 above) 217-218.

130 Southern Cameroon (n 2 above) paras $102 \& 108$. 
human being and the integrity of the person. ${ }^{131}$ Similarly, cases of detention without trial followed by release, and also the violent suppression of demonstrations and/or unlawful arrest and detention of demonstrators were respectively found to be in violation of article 6 of the African Charter on the right to liberty and to the security of one's person, and article 11 on freedom of assembly. ${ }^{132}$ The transfer of arrested individuals from Southern Cameroon to Francophone Cameroon for trial by military tribunals and trials of others in civil law courts without interpreters were found to be in violation of the due process guarantees under article $7(1)$ of the African Charter. ${ }^{133}$ Acts of torture and amputation and the denial of medical treatment amounted to violations of article 5 of the African Charter prohibiting, among others, torture and cruel, inhuman or degrading punishment and treatment. ${ }^{134}$ The African Commission also found that the lack of independence of the Cameroonian judiciary violated article 26 of the African Charter. Following a positive finding of violations of several provisions of the African Charter on individual rights, the Commission concluded that Cameroon violated its obligation under article 1 to guarantee the rights, freedoms and duties enshrined in the instrument. ${ }^{135}$ The Commission was unable to find violations of article 3 (equality before the law), article 9 (the right to receive and disseminate information), article 10 (freedom of association), article 12 (freedom of movement), article 13 (the right to participate in the public life of the country) and article 17 (rights to education and to participation in the cultural life of the community) since the applicants did not elaborate thereon or support their claims. ${ }^{136}$

Under peoples' rights provisions of the African Charter invoked by the applicants (articles 19-24), the African Commission found only a single violation. It ruled that the relocation of business enterprises and the location of economic projects to Francophone Cameroon violated article 19 (on peoples' rights to equality and their freedom from domination) since it had a negative effect on the economic life of Southern Cameroonians. ${ }^{137}$ However, the Commission found no violations of Southern Cameroonians' rights to freely dispose of their wealth and natural resources (article 21 ), to peace and security (article 23(1)) and to a general satisfactory environment (article 24) because, it was ruled, the applicants had failed to submit evidence in support of their allegations. ${ }^{138}$ Moreover, under article 22, the African Commission reiterated the obligation of a state to use its resources in the best way to ensure the progressive realisation of the right to

131 Southern Cameroon paras 110-112.

132 Southern Cameroon paras 115-120 \& 134-138.

133 Southern Cameroon paras121-131.

134 Southern Cameroon paras 113-114.

135 Southern Cameroon para 213.

136 Southern Cameroon paras 109, 132-133 \& 139-149.

137 Southern Cameroon paras 151-162.

138 Southern Cameroon paras 204, 207 \& 208. 
development, but laconically determined that the inability of a state to 'reach all parts of its territory to the satisfaction of all individuals and peoples' cannot, in itself, be deemed to be a violation of the right to development. ${ }^{139}$

Following a more elaborate reasoning, the African Commission also did not find a violation of the right to self-determination (article 20) at the heart of the communication. International norms and jurisprudence as well as academic literature have elaborated on the right to self-determination with its internal dimension (within the boundaries of a state) and external dimension (breaking away from a state). ${ }^{140}$ A reading of the substantive claims by the applicants in the South Cameroon case clearly shows that they sought to exercise external self-determination in the form of secession from the Republic of Cameroon. Under article 20 of the African Charter, the African Commission found that the inhabitants of Southern Cameroon could legitimately claim to be a people since they identified themselves as such and shared 'numerous characteristics and affinities, which include a common history, linguistic tradition, territorial connection, and political outlook'. ${ }^{141}$ The Commission examined at length the self-determination claims of the applicants on the basis of events postdating the entry into force of the African Charter. ${ }^{142}$ Reiterating its previous position held in Katangese Peoples' Congress $v$ Zaire, ${ }^{143}$ the Commission ruled that it was obliged to uphold the territorial integrity of the respondent state as secession was not 'the sole avenue open to Southern Cameroonians to exercise the right to selfdetermination'. ${ }^{144}$ The African Commission unequivocally suggested that the applicants should consider alternative options, such as autonomous rule in the form of self-government, confederacy or

139 Southern Cameroon para 206.

140 For relevant analyses, see J Summers Peoples and international law: How nationalism and self-determination shape a contemporary law of nations (2007); J Crawford 'The right to self-determination in international law: Its development and future' in Alston (n 5 above) 7; J Klabbers \& R Lefeber 'Africa: Lost between selfdetermination and uti possidetis' in C Brölmann et al (eds) Peoples and minorities in international law (1993); SF van den Driest Remedial secession. A right to external self-determination as a remedy to serious injustices? (2013).

141 Southern Cameroon (n 2 above) paras 178 \& 179.

142 Southern Cameroon para 182. The African Commission misstated the facts by referring to 'the 1972 Unification'.

143 In Katangese Peoples' Congress v Zaire (2000) AHRLR 72 (ACHPR 1995), the African Comission held that '[s]elf-determination may be exercised in any of the following ways - independence, self-government, local government, federalism, confederalism, unitarism or any other form of relations that accords with the wishes of the people but fully cognisant of other recognised principles such as sovereignty and territorial integrity' (para 4). To these ambiguities (pitting independence and territorial integrity) one needs to add the fact that the African Commission declined to clearly determine whether the Katangese constituted a people.

144 Southern Cameroon (n 2 above) paras 190-191. 
federation that would not jeopardise the territorial integrity of the Cameroonian state. ${ }^{145}$

Unlike in the Endorois case, the African Commission declined to adjudicate on claims of forceful annexation and colonial occupation of Southern Cameroon by the respondent state since these fell outside its temporal jurisdiction: The alleged events took place prior to the entry into force of the African Charter for Cameroon on 18 December 1989. The Commission reiterated its jurisprudential position that only violations that occurred prior to, but which continued after, this date could be adjudicated. It remains unclear which aspects of continuous violations can be adjudicated. The decision embodies a paradox whereby the African Commission declined to adjudicate on the legality of the 1961 plebiscite and of the 1972 referendum and, yet, managed to find that the inhabitants of a territory no longer existent at the time of the entry into force of the African Charter constituted a people.

Furthermore, the African Commission missed a good opportunity to unequivocally lift the ambiguities underpinning its decision in the Katangese People's Congress case with regard to whether victimised people have a right to exercise the right to external self-determination (secession) from a state that committed massive violations of human rights, or denied them their right to participate in public affairs. ${ }^{146}$ Instead of using the Gunme case to clarify the matter, the African Commission made a very dubious interpretation of both the right to self-determination under the African Charter and its own jurisprudence in the Katangese People's Congress case. Article 20(1) of the African Charter provides that all people 'have the unquestionable and inalienable right to self-determination'. Since the Commission determined in Gunme that Southern Cameroonians are a 'people' under the African Charter, there should be no question that they are then entitled to an 'unquestionable and inalienable right to selfdetermination'. The ruling in the Katangese People's Congress case relating to violations of human rights and the denial of participation rights can only be helpful in determining the form of selfdetermination that the applicants may exercise, not whether they may exercise it. Yet, the African Commission invoked the Katangese People's Congress decision in affirming that 'the right to selfdetermination cannot be exercised in the absence of proof of massive violations of human rights under the Charter' ${ }^{147}$ This statement seems to condition the exercise of the right to self-determination to a proof

145 Southern Cameroon para 191.

146 In the Katangese Peoples' Congress case (n 143 above), para 6 the African Commission held that the applicants were obliged to exercise a variant of selfdetermination that is compatible with the sovereignty and territorial integrity of Zaire since there was no concrete evidence of violations of human rights to the point that the territorial integrity of Zaire should be called to question or in the absence of evidence that the people of Katanga [were] denied the right to participate in government.

147 Southern Cameroon (n 2 above) para 199 (my emphasis). 
of massive human rights violations or a denial of participation rights. It clearly misinterprets the Katangese People's Congress decision suggesting - even though ambiguously - that secession may be invoked in such extreme cases. Furthermore, the statement contradicts the subsequent affirmation in the same paragraph that the 'various forms of governance or self-determination such as federalism, local government, unitarism, confederacy, and self government can be exercised only subject to conformity with state sovereignty and territorial integrity of a state party'. ${ }^{148}$ Finally, the finding that 'Southern Cameroon cannot engage in secession, except within the terms expressed hereinabove, since secession is not recognised as a variant of the right to self-determination within the context of the African Charter' hardly makes any sense. ${ }^{149}$ The wording of this particular section displays a lack of analytical rigueur by the drafters of the African Commission decision.

The cause for independent statehood of Anglophone Cameroon central to the applicants' case - but also championed by organisations such as the Southern Cameroons National Council (SCNC) and the Southern Cameroons People's Organisation (SCAPO) - was not in any way vindicated by the ruling. The African Commission urged Cameroon to remedy violations of the applicants' rights and formulated recommendations for all parties to use other peaceful means, such as constructive or comprehensive national dialogue, to find a lasting solution to the problems used as grounds for Anglophone secession. ${ }^{150}$ The Southern Cameroon decision, like the Endorois decision, raised some questions over what collective represents a people and, more generally, over the interpretation of the peoples' rights provisions of the African Charter.

\section{Appraisal: Ambiguities of the African Commission on peoplehood and indigenous rights}

The Endorois and Southern Cameroon cases offer two contextually different illustrations of the dynamic interpretation of the peoples' rights provisions of the African Charter. In the first case, the African Commission agreed with the applicants that members of the relatively small Endorois community - previously considered as just one among many clans of the Tugen, a sub-unit of the Kalenjin community - were indeed an indigenous people whose collective rights under the African Charter had been violated. In the second case, the Commission found only one substantive violation of peoples' rights, but nevertheless applied the peoplehood attribute to the ethnically diverse inhabitants of the former British territory of Southern Cameroon that had

148 As above.

149 Southern Cameroon (n 2 above) para 200 (my emphasis).

150 Southern Cameroon paras $203 \& 215$. 
acquired independence through reunification with the Republic of Cameroon. The progressive interpretation of peoples' rights has very commendable advantages, but also embodies potential dangers.

The jurisprudence of the African Commission on collective rights displays an open range of possibilities in using the African Charter to address the predicament of particularly vulnerable collective identities. The inherent flexible nature of the African human rights system, whereby individuals and collectives may seek redress for human rights violations or for patterns of socio-political and economic exclusions, is an important tool in an effort to build more accountable and inclusive African polities. Yet, the very flexibility of the African Charter system in receiving communications from a variety of sources and the increasingly expansive interpretation of the peoples' rights provisions of the African Charter by the African Commission can potentially be exploited for politicised and divisive agendas within fragile African polities.

The practice of the African Commission displays the institution's readiness to apply the 'peoplehood' attribute to a wide range of societal groupings. First, the Commission has used 'people' to refer to the entire population of a country. ${ }^{151}$ In this case it does not matter whether the population is ethnically, racially or religiously homogenous or heterogeneous. Inhabitants of Nigeria, Cameroon, South Africa, Lesotho, Swaziland or Burundi may all be considered as peoples. Under international legal theory and practice, this is the most conventional and least contested usage of 'people(s)' ${ }^{152}$ After all, the decolonisation process of African and other countries was celebrated as an exercise of peoples' rights to self-determination. ${ }^{153}$

Second, the concept has also been used in reference to a single ethno-linguistic/cultural community within a multi-ethnic country. ${ }^{54}$ In the particular context of the African continent, harbouring numerous ethno-cultural communities, it is yet to be clarified what collective identities qualify as peoples. Since the Endorois were and are still identified as constitutive of a sub-unit of the Tugen and Kalenjin groups, the African Commission should have clarified whether the three levels of community identification constitute one or several people(s). Prior to the current expansion of the indigenous rights movement, international legal theory insisted that 'people should not be confused with ethnic, religious or linguistic minorities,

151 See eg Jawara $v$ The Gambia (2000) AHRLR 107 (ACHPR 2000), where the African Commission refers to 'the Gambian peoples' (para 72) and 'the Gambian people' (para 73). In the Democratic Republic of Congo case (n 86 above), the African Commission referred to 'the people(s) of the Democratic Republic of Congo' (paras 68 and 77 for 'peoples'), para 95 for 'people') and 'Congolese' peoples (para 87).

152 Summers (n 140 above) 1-2.

153 United Nations Declaration on the Granting of Independence to Colonial Countries and Peoples, GA Res 1514 (XV) 14 December 1960.

154 It was applied to the Ogonis in the Ogoni case (n 25 above) paras 1 et seq, and to the Endorois in Endorois (n 3 above) paras 145-162. 
whose existence and rights are recognised in article 27 of the International Covenant on Civil and Political Rights'. ${ }^{155}$ The African Charter system did not adopt the differentiation between minorities and peoples. ${ }^{156}$ The instrument merely provides for peoples' rights. There are no undisputable legal grounds for considering some groups as minorities but not peoples under the African Charter. The jurisprudence of the African Commission suggests that beyond normative considerations, the distinction may be of limited practical relevance in the African context. In a context such as Kenya, the applicability of peoples' rights provisions to specific ethno-cultural communities suggests that the Endorois (but also Tugen and Kalenjin), the Kikuyu, the Luo, the Ogiek or the Nubians may all be considered as peoples under the African Charter, regardless of the indigenous or non-indigenous status of each one of these communities. In the case of the Nubians, CEMIRIDE and other actors capitalised on the Endorois precedent in presenting a communication to the African Commission for the recognition of civil and other rights of members of the Nubian community living for roughly a century in Kenya. ${ }^{157}$ Reportedly numbering between 20000 and 100000 individuals, the Nubians settled in Kenya since the colonial era, but have always been considered as non-nationals, a situation that renders them virtually stateless. ${ }^{158}$

Finally, the African Commission has used 'people' or 'peoples' to describe a non-homogenous population of a particular geographic area or a racial group within a specific country. ${ }^{159}$ This represents the most uncommon conceptualisation of peoplehood. Used in the plural form, 'peoples' of a region suggests that the concept is used to refer to the various ethno-cultural communities under the second meaning discussed above. It implies that the particular geographic area to

155 See The Right to Self-Determination: Historical and Current Development on the Basis of United Nations Instruments: Study by Aureliu Cristescu, Special Rapporteur of the Sub-Commission on Prevention of Discrimination on Protection of Minorities, 1 January 1981, UN Doc E/CN.4/SUB.2/404/Rev 1, para 279.

156 See more generally S Slimane Recognising minorities in Africa (2003).

157 The Nubian Community in Kenya $v$ The State of Kenya, African Commission Communication 317/06, http://www.soros.org/initiatives/justice/litigation/ali/alicommunication-20100517.pdf (accessed 26 August 2010). The communication made numerous references to the Endorois case as in paras 162-164 and 175.

158 Nubian Community (n 157 above) para 5. The African Commission decision in the case focused more on the recognition of their citizenship and property rights than on peoples' rights. See Communication 317/2006, The Nubian Community in Kenya $v$ Kenya, Thirty-Eighth Activity Report (ACHPR 2015).

159 As in 'the people of Katanga' (Katangese Peoples' Congress case (n 143 above) para $6) ;$ 'the peoples of the eastern province[s] of the complainant state' (Democratic Republic of Congo case (n 86 above) para 87); 'Black Mauritanians' in Malawi African Association \& Others v Mauritania (2000) AHRLR 149 (ACHPR 2000) paras 139-142. 
which it is applied is inhabited by not one but several peoples. The singular form, as in 'people of Darfur' ${ }^{160}$ or 'people of Casamance', 161 is more problematic. The criteria under which the inhabitants of a given geographic subdivision of a country can be considered as a people are far from clear. In some cases, it is difficult to determine whether 'people of' a specific area - as in 'people of Northern Uganda' 162 - is used within the colloquial meaning of 'inhabitants of', or whether the notion fits within the specific meaning of the peoples' rights provisions of the African Charter. In the same vein, the African Commission has applied peoples' rights provisions to 'Black Mauritanians', ${ }^{163}$ even if this population does not represent a homogenous group. ${ }^{164}$ It is not quite clear, in this particular case, whether the various groups of black Mauritanians constitute 'a people' or 'peoples' under the African Charter.

Thus, it follows from the jurisprudence and practice of the African Commission that there are several intertwined layers of peoples within single, mostly multi-ethnic African states. The Commission has displayed - explicitly or implicitly - a readiness to consider that the Endorois, the Southern Cameroonians, the Ogonis, the Black Mauritanians, the Katangese; the entire Congolese, Sudanese, Senegalese populations or the native inhabitants of their respective Eastern Congo, Darfur or of Casamance provinces, are people(s) under the African Charter. Applying substantive rights assigned to peoples under the African human rights regionalism and, more generally, under international law, to all these collectives may raise some questions of consistency. Do all ethno-cultural communities in a country or only some of them have a right to self-determination? What substance - socio-political, economic, cultural and territorial dimensions - should be attached to such rights? What should state parties such as Cameroon, the Democratic Republic of the Congo and Nigeria - with hundreds of different ethno-cultural communities each - do to ensure compliance with their obligations under the relevant provisions of the African Charter and other instruments, such as the Declaration on the Rights of Indigenous Peoples? ${ }^{165}$ These questions

160 African Commission 'Report of the African Commission on Human and Peoples' Rights' Fact-Finding Mission to the Republic of Sudan in the Darfur Region (8-18 July 2004)' 22nd Activity Report (2007), EX CL/364 (XI), Annex III, paras 151 and 6 refers to 'the people of Darfur' (para 6) and to the peoples of Sudan (as in para 151).

161 African Commission 'Report on the Mission of Good Offices to Senegal of the African Commission on Human and Peoples' Rights (1-7 June 1996)' 10th Annual Activity Report 1996/1997, Annex VIII, Sections V, 3 (12) and VI mentions of the people of Senegal and the people of Casamance (in the conclusions and recommendations).

162 African Commission 'Resolution on the Human Rights Situation in Uganda' 20th Activity Report (2006), EX CL/279 (IX), Annex III, para 5.

163 Malawi African Association (n 159 above) paras 139-142.

164 Malawi African Association paras 140-142.

165 United Nations Declaration on the Rights of Indigenous Peoples, UN Doc A/61/ L.67 12 September 2007. 
remain widely unanswered under the current jurisprudence of the African Commission.

Finally, in the Endorois case, as in other relevant work of the African Commission, the institution has so far failed to make a convincing case on why the indigenous legal framework was needed in the African human rights regionalism. As stated earlier, the 2001 ruling in the Ogoni case clearly showed that the provisions on individual and collective rights in the African Charter could be used to seek redress for violations of the rights of a particularly marginalised community without necessarily resorting to the indigenous rights legal theory. The boundaries between activism for the recognition of indigenous rights and the interpretative mandate of the African Commission are not clearly delineated in the Endorois decision. It was possible for the Commission to find violations of the applicants' individual and collective rights without relying too much on the contentious indigenous rights theory and jurisprudence as mainly developed in the historically and contextually different Latin American landscape. ${ }^{166}$

166 For more, see FM Ndahinda 'The future of indigenous rights in Africa: Debating inclusiveness and empowerment of collective identities' in R Dunbar-Ortiz et al (eds) Indigenous peoples' rights in international law: Emergence and application - A book in honour of Asbjörn Eide at eighty (2015). 